\title{
Motivation and resistance as predictors of sports practice expectations: a case study of the Physical and Sports Activity students of the Central University of Ecuador \\ Motivaciones y resistencias, e imagen del profesorado de actividad física y deportiva como predictores de expectativas de práctica: estudio de caso de los estudiantes de la Universidad Central de Ecuador
}

Jenny Esmeralda Martínez Benítez, Lluisa Aitana Sauleda Martínez

Universidad de Alicante (España)

\begin{abstract}
This study analyzes factors that may influence the expectations of practicing future sports. Among these factors, the motivation and resistance towards the practice of physical activity and sports from 300 students of the Central University of Ecuador are analysed. The metaphorical constructions of the students are also interpreted in relation to the impact that the physical activity and sports -PAS has in their personal lives. The metaphorical constructions of the students, in relation to the meaning that the PAS represents in their personal life are also considered and the students' perception of their Physical activity and Sports teachers also is requested. Finally, the expectations of PAS practice that they express are taken into account. The methodology is qualitative with an interpretative approach. The data collection technique is an interview that allows you to understand the problem from the perspective of its protagonists. In the data processing, the Aquad 6 computer program is used, which allows the analysis of the narratives through categories and codes. The results show that motivation exceeds resistance, and that the lack of time is its great difficulty to practice. In the study of metaphors, the level of satisfaction indicated, coincides with the metaphors of the value of PAS in personal life as a source of well-being and health. The findings show high expectations which could be correlated with the positive satisfactions in practice, the image of the teaching staff and the vital relevance they attach to the PAS.
\end{abstract}

Keywords: physical and sports activity practice, university students, driving force and resistance, teacher vision and practice expectative.

Resumen: Esta investigación analiza factores que pueden influir en las expectativas de práctica deportiva futura. Específicamente, se analizan las motivaciones y resistencias hacia la práctica de actividad física y deportiva de 300 estudiantes de la Universidad Central del Ecuador. Asimismo, se analizan las construcciones metafóricas de los estudiantes en relación al sentido que la actividad física y el deporteAFD representa en su vida personal. Estos resultados se relacionan con la percepción que los estudiantes tienen de su profesorado de Actividad Física y Deportiva y con la representación metafórica de la imagen del profesor de AFD que se les solicita. Finalmente, se analizan las expectativas de práctica de AFD que manifiestan. La metodología es cualitativa con un enfoque interpretativo. La recogida de datos se registra mediante una entrevista que permite comprender la problemática desde la perspectiva de sus protagonistas. En el procesamiento de datos se utiliza el programa informático Aquad 6, que posibilita el análisis de las narrativas a través de categorías y códigos. Los resultados evidencian que la afección supera a la resistencia, que la falta de tiempo es su mayor dificultad para la práctica. En el estudio de metáforas, las satisfacciones señaladas, la salud y la satisfacción en la práctica, coinciden con las imágenes del valor de la AFD en su vida personal como fuente de bienestar y salud. La opinión sobre el profesorado es positiva y la imagen metafórica muestra una visión idealizada del profesor en el que quieren convertirse. Los hallazgos muestran altas expectativas lo que podría correlacionarse con las positivas satisfacciones en la práctica, la imagen del profesorado y la vital relevancia que conceden a la AFD.

Palabras clave: práctica de actividad física y deportiva, estudiantes universitarios, motivación y resistencia, imagen del profesorado y expectativas de práctica.

\section{Introduction}

The use of student voices in Physical Activity and Sports research-PAS, is a necessary methodology if we want all the complex variables that affect knowledge of the field to be considered. On the other hand, in the social, curricular and academic field we cannot expect any democratization of the PAS environment without considering the students' cognitive and emotional processes. Attending to and analyzing the voices of students allows us to involve them in educational decisions (Enright, Coll, Ní Chróinín, \& Fitzpatrick, 2017). We cannot forget that authentic learning needs reflection in collaborative and situated processes. All this contributes to a scientific action in the PAS spaces. Sfard and Prusak (2005) defend the narratives and life experiences to investigate learning as a culturally shaped activity. Individual identity is reflected in our voices and narratives, stories about ourselves, which when agglomerate

Fecha recepción: 11-09-19. Fecha de aceptación: 23-01-20

Lluisa Aitana Sauleda Martínez

lasm@alu.ua.es it in a certain context, become a collective voice of a given context. The aforementioned authors stress the need to take into account the thinking, beliefs, attitudes and values of the PAS student in order to know the social and cultural influence from their environment. Numerous sport field researchers have used strategies that allow athletes to express their difficulties and needs. In this sense, Van Raalte, Vincent and Brewer (2016) propose the strategy of «self-talk», used by teachers and coaches as an internal and reflective dialogue, whether verbalized or written. In the self-talk we can appreciate victimization or decisive attitudes that effect an athlete's behaviour. Other researchers such as Whitehead, Jones, Williams, Rowley, Quayle, Marchant and Polman, (2018) and Taylor (2017) have used cognitive and emotional strategies such as thinking out loud or self-reported as research tools. Athletes who verbalized their mental and somatic states about the task were benefited by the strategies according to the mentioned authors.

In addition to cognition and emotional perspectives, we have used metaphors in our research as an instrument of student thought analysis. In education research, an effective way to discuss students or teachers thinking is through 
metaphors (Martínez et al., 2017). Students treasure a personal and social history, often intuitive and unconscious, which leaves an indelible mark on their mind, and could mark certain behaviour of action in their future professional practice. This belief is difficult to change as long as they do not consciously analyse it, hence its importance.

Rhodes, McEwan and Rebar (2019) place the perspective of Kahneman (2000), which establishes two systems of thought, as a dual theory. Kahneman (2011) in this dual perspective called System 1 of thought as a fast, intuitive and emotional thinking. In a sense it is in line with the personal metaphors, used in research to discover non-reflexive, spontaneous thoughts and derived from previous and cultural experiences not mentally processed. System 2 , referenced by the aforementioned author, identifies a slower, conscious and reflective thought, for example when students write reflective diaries. The context has to do with both systems, because there may be a social context of support for shared reflection, or a context that precipitates actions and thoughtless responses.

With this consideration, we have selected interpretive research as a strategy for collecting and interpreting this kind of information. Our intention is to use the analysis of the student's thinking to recognize predictors of voluntary practice.

\section{Motivation and resistance to physical activity and sports of university students as predictors of future practice}

The students' satisfaction and resistance can be a predictor of their intention to persevere in sports practice in the future. Researchers as Ryan y Deci (2017) study the motivation applied to teaching and learning developing the so-called perspective of self-determination. Following this line, McDavid, Cox and McDonough (2014) find that levels of autonomous regulation and achievement are positive predictors, while absence of motivation or lack of selfregulation capacity complicates continuity (Brick, 2015). Along these lines, Behzadnia, Adachi, Deci and Mohammadzadeh (2018) investigated whether strategies to support student autonomy versus steering control influenced persistence in the practice of PAS finding that students felt better motivated with the strategies of support for autonomy while directive control produced more frustration, abandonment and low persistence.

Undoubtedly, the expectations of PAS practice in leisure time depend on an adequate balance between motivation and determination, driving force and difficulties. The motivation to continue practicing outside the regulated teaching environments may have increased thanks to several factors, for example the passion of the PAS teacher, and his methodological strategies as explained by Reeve (2016) and Ryan and Deci (2019). Teachers who have used self-regulation and autonomy have better prepared students to voluntarily continue with the PAS. Human needs regarding autonomy, achievement, socialization, and decision making require a teacher capable of creating a learning environment appropriate to these needs if you want to achieve a path of determined intentions in the student regarding the practice of PAS

Haerens, Kirk, Cardon, De Bourdeaudhuij and
Vansteenkiste (2010) investigated the motivational levels of high school students and their relationship with PAS practice in college. Taking data from the UK and Belgium, they infer that there is very little transfer between PAS practice in Secondary Education and university level practice. The opinion of the university students is that the PAS of Secondary Education has not prepared them to be involved in PAS outside of regulated education. PAS occurs in a complex learning environment that includes teaching strategies used by teachers, intended results, and motivational climate, so it is difficult to identify the variables of demotivation. However, it is widely accepted that the practice of PAS influences future expectations. For example, De Meester, Haerens and Cardon (2017) investigated whether extracurricular practice is a predictor of future involvement in that practice. On data on the participation of students who are offered extracurricular practices, they conducted a study in Belgium and found that students who participated in extracurricular practices had higher expectations and motivations to continue (Cloes, 2017).

Of course, the weight of the context and the economic, family, labour and cultural difficulties also count to a great extent. And each of them can be accompanied by demotivation and resistance. Research in PAS needs to incorporate the cultural and ethnic context into its agenda (Weinberg et al., 2000) since most research hadn't been produced until a few decades ago in North America. Until the 90 s there were not even $10 \%$ of studies published outside these perimeters, which has promoted a dominant vision in PAS research. In disadvantaged context it is necessary to consider factors such as resilience or strength to resist in such adverse context (Hill, Den Hartig, Meijer, De Jonge \& Van Yperen, 2018). Studies are needed on the basis that there are contexts where the most basic needs can be superimposed on the needs described by the theory of selfdetermination (Deci \& Ryan, 2016), for example there are countries where transport is a big problem, buses are insecure, running around the city is reckless, and a student's economy does not allow him to train, so all of this must be considered.

With this intention, this research seeks to see the influence of the relationship between motivation, resistance and image of teachers in expectations and intentions to voluntarily persecute PAS in the future, in students from a Latin-American country.

\section{Metaphorical images as predictors}

The construction of metaphors is based on the consideration that we learn from our experience and the social relationship during our life trajectory. This learning marks our disposition, motivation and goals in life. Somehow learning such an environment shapes us, as our brain and mind conforms our learning. In this process, we tend to turn our experiences in metaphorical stories that give meaning and expression to our life, our thinking and our emotions. Metaphors is an interplay between experience, context and mind. Not only keeping the footprint of our past history, metaphors also aim at objectives and driving us to action (Saban, 2010). A prolific number of researchers have chosen metaphorical narratives as a tool of research. We must not 
forget that we are social beings and our life experiences are social experiences. The metaphors of our lives become mental models through a social and cognitive dialectic (Lakoff \& Johnson, 1999). Metaphorical stories are determined by the processes of enculturation, which are reflections of a particular culture. This allows us to observe and mentally process our environment (Saban, Kocbeker, \& Saban, 2007).

The persistence of beliefs and their impact on personal identity requires its verbalization and assumption. The construction of educational metaphorical stories is an intuitive act that intersects life experiences, socialized and conceptualized their school life history. Following this argument, Mahlios, Massengill Shaw and Barry (2010) consistently emphasized that one way to examine the beliefs of students in initial teacher education is to identify the conceptual tools they use to make sense of their life, with the metaphor being the most powerful resource. As Rosaen and Florio-Ruane (2008) point out that metaphors conglomerate beliefs, knowledge, feelings and actions that guide practice. Thus, the metaphorical stories could help make the diluted students' conceptions conscious.

How can PAS teachers in the university field and metaphorical images of previous experiences become predictors of PAS in students?

There are two factors inherent in teaching. The personality of the teacher and his methodologies. These two factors help to create a certain climate or learning space. Normally there is a high correlation between both factors. An executive professor, does not usually use autonomous learning methodologies, or student-centered learning, and if he does, then he will not be able to create a real autonomous environment.

Gutiérrez, Tomás and Catalayud (2017) have underlined the role of the PAS teachers to develop disposition and propulsion towards physical activity. An authentic PAS teacher is expected to expand students' opportunities to learn, participate and benefit from PAS inside and outside academic centers. The teacher is a model, an image for their students, the commitment and responsibility that entails requires a great passion for PAS (Asún, 2010). The teaching staff establishes the scaffolding and the environment that supports or limits the opportunities that the student can obtain from PAS learning. Ayvazo, Ward and Stuhr (2010) highlight that the mastery of the contents and their skills by teachers are positive influences on students. Other researchers, Whittle, Telford and Benson (2015) highlight the positive response of the student to teacher availability and empathy, and to the delegation of responsibility showed that what works best in Physical Education are those classes where the teacher gives students a choice of tasks and knows how to use the rules of play for creating a democratic atmosphere in the classroom (Cothran et al.,2005). The physical education settings are relevant factors; those methodologies fostering motivation, autonomy and decisionmaking by students can provide greater satisfaction, interest and even higher levels of formal physical activity outside the educational setting (Krijgsman, Mainhard, Tartwijk, Borghouts, Vansteenkiste, Aelterman \& Haerens, 2019).

On the contrary, Shen, Sun and Bernard (2010) found that the teacher's lack of support leads to demotivation. This absence of support produces low expectations of future practice in the student. In this sense, students held that they disliked physical education classes because they did not like the teacher. Highlighted aspects such as the hurdles perceived by students, were lack of purpose and poor and monotonous activities. It is therefore the responsibility of physical education teachers to design a curriculum using the most up-to-date information, organizing activities to meet the needs of all students (Chen \& Hypnar, 2015) and engaging them in learning, but above all creating a suitable environment for learning. Therefore, it is important to consider the students' perception of their teachers (Larsson \& Quennerstedt, 2016).

In addition, the cultural context of each society that affect students. Not all responsibility for success or failure can be attributed to teachers. Morgan and Hansen (2008) find how teachers contemplate institutional barriers such as lack of time, resources, large groups, and marginalization of the PAS. The lack of confidence, knowledge and experience of teachers are described as predictors of low quality teaching. The situation has been diagnosed but has not changed. Neither professional development nor resources improve, which shows that despite the alert of international organizations little is done and less is invested. As Cecchini et al. (2001) summarizes the influence of teachers in intrinsic motivation and involvement, it is necessary that teachers are qualified to create a stimulating environment.

Serra, Zaragoza and Generelo (2014) study the influences of parents, friends and teachers. Most studies, such as Van der Horst (2007), highlight the influence of friends, and other studies see the influence of teachers as negative (Trudeau \& Shepard, 2005). Cox, Duncheon and McDavid (2009) see both teachers and classmates as a resource for students' disposition in relationships, motivation and emotional response. Both influence motivation and enjoyment if there is teacher support and friendship and acceptance by both parties. Similarly, Woods, Tannehill and Walsh (2012) find enjoyment as the most influential motive that affects participation in physical activity and, likewise, conclude that student enjoyment and attitudes of Physical Education classes would increase if students were provided with a more appropriate learning environment and add that, in addition, students are more likely to enjoy their experiences and maintain intrinsic motivation by conducting PAS outside of schools.

In the study by Li, Chen and Baker (2014) positive attitudes were strongly associated with obtaining physical, personal and social benefits of Physical Education. As the authors have demonstrated support strategies, they must be accompanied by a structured learning environment that prevents the student from feeling lost (Reeve, Ryan, Deci, \& Jang). This support works best, in our research (Ávalos, Martínez, \& Merma, 2017) when produces in a scenario of collaborative practices where the objective is common and support offered to the group rather than to the individual. In the autonomous group, prosocial and mutual help behaviors are more frequent (Cheon, 2018).

In accordance with Romar, Åström and Ferry (2018) preservice teachers are influenced by previous acculturation 
experiences. Therefore, both the reflective opinion of the student about his current PAS faculty, and the intuitive image taken from previous experiences that are configured through metaphors (Martínez, Ávalos, \& Merma, 2017) can be instruments of reflection and debate to integrate meaningful new experiences.

\section{Research context}

In Latin America, the landscape of physical inactivity is increasingly worrying. The latest data from the World Health Organisation -WHO, confirms this. Although Ecuador has better rates than other countries, $27 \%$ of its population still does not meet the minimum (Guthold, Stevens, Riley, \& Bull, 2018). Another important element of analysis in this context is the fact that physical inactivity differs according to socioeconomic level, thus people of lower socioeconomic levels tend to be more inactive. The study of Guthold et al. (2018) aims that more than $40 \%$ of the population is irregularly active in Latin America. Similarly, the latest survey of sports habits in Ecuador (Ministerio del Deporte de Ecuador, 2012) determines a sedentary behaviour in the Ecuadorian population, since $51 \%$ of respondents do not practice any sport. Additionally, the Survey Living Conditions 6th round 2015 (INEC, 2015) reveals that $80 \%$ of children between 5 years and under 10 years spend at least two hours a day in front of the TV. In Spain, we found research on the relationships between digital technologies, sedentary lifestyle and physical activity, for example, Beltrán et al. (2017) reports how adolescents with better health status have low sedentary behavior frequencies, as well as Golpe, Isorna, Gómez and Rial (2017) who underline the negative relationship between intensive internet use and sports practice.

In the case of the university population, the investigations carried out also reveal problems with the practice of physical sports activity of the students (Martins et al., 2019). In the university context in Latin America or Ecuador, studies show the transition from one stage to another is identified as one of the critical moments for abandoning the practice of physical activity and sport. Gómez, Sánchez and Labisa (2020) points out in the case of university students, possibly the fact of facing new situations such as the beginning of their university studies where they have to face demands regarding their academic performance, they can lead to a sedentary lifestyle. Also, they confirm this criterion and assert that research in Spain determines that the proportion of practitioners involves increasing the age, until reaching a time when the decrease in practitioners is high, and coincides with the age range of 18 to 25 years. In addition, the beginning of a university career usually implies a decrease in physical activity levels.

In this conceptual framework outlined, we have designed the research issues that have guided the study:

1. What motivation and resistance to the practice of physical activity and sports that the students of the Central University of Ecuador express?

2. What image of the PAS faculty do the students of the University of Central Ecuador perceive?

3. Which expectations of the practice of physical activity and sports do the students of the Central University of Ecuador maintain?

\section{Research Methodology}

Using an intentional and dynamic sample, students from the Central University of Ecuador were invited to participate. 300 students decided to do so voluntarily, most of them belong to the Faculty of Physical Culture, the remaining participants were student from different faculties who have chosen optative subjects from the Physical Culture curriculum, then all of them were-linked to the practice of physical and sports activity. The $43.33 \%$ represent the male gender and $56.67 \%$ represent the female gender. The age of the students ranges from 18 years to 29 years.

The data collection instrument has been the semistructured interview to access the thoughts and opinions of the participants. Individual written interviews were conducted, prior to the signing of the informed consent, information on the objectives of the study and the guarantee of the confidentiality of the information and anonymity of the participants.

For the data processing and analysis, the Aquad software program, developed by Huber and Gurtler (2013) was used. This program allows to identify, categorize and codify the units of meaning, and helps to relate categories and draw conclusions. Once the interpretative analysis of the emerging units of the narratives was carried out, a coding instrument was developed, recursive triangulation between researchers were performed until a definitive categorical map was obtained. For the presentation of the findings, tables of absolute and relative frequencies were developed, showing the interrelationships of codes. The research both for its conceptual framework -the analysis of the voices and thoughts of the students-, and for their narrative procedure of analysis is part of the qualitative paradigm, however we have added frequencies as a means of clarifying and visualizing results, usual fact as complement to qualitative interpretation. The exemplification of codes we believe helps the qualitative understanding of the results. The problem of concision limits the amount of narratives that can be presented.

\section{Presentation of results}

The present results contain the ordered sequence of partial results. In the Discussion the interrelation between categories is discussed in order to add coherence and consistency to the research. The description of the data is supported, in a complementary way, with tables and figures that show the absolute frequency (FA) of each code or number of times that participants narratives refer a determined code and the correspondent absolute frequency percentage $(\%$ FA).

\section{Satisfaction and resistance towards the practice of physical and sports activity}

In this section, the motivation that lead the students towards the practice of PAS is analyzed, as well as the causes of disaffection or resistance that move them away from it. Alongside the tables are some narratives of the participants that exemplify the coding performed. 


\section{Satisfactiontothepractice of physical activity bystudents}

Table 1.1

Motivation that lead students to choose a physical activity

\begin{tabular}{lcc}
\hline Codes & Participants narratives & \\
\hline & $\mathrm{AF}$ & $\mathrm{AF} \%$ \\
\hline 1.1.1 Personal satisfaction / entertainment & 116 & 31,18 \\
1.1.2 Health & 183 & 49,19 \\
1.1.3 Aesthetic & 21 & 5,64 \\
1.1.4 Mental and emotional control & 14 & 3,76 \\
1.1.5 Socialization & 9 & 2,41 \\
1.1.6 Professionalization & 16 & 4,30 \\
1.1.7 Obligation /No practical & 11 & 2,95 \\
1.1.8 Economic improvement & 2 & 0,53 \\
\hline Total & 372 & \\
\hline
\end{tabular}

As can be seen in Table 1.1, according to the narratives of the students interviewed, the main reasons are health, satisfaction and enjoyment:

It relaxes me a lot and helps me keep my body and soul healthy (Participant 25).

I do it to maintain good health, also to avoid being overweight and for a better quality of life (P.168).

The attraction and passion satisfaction and motivation of university students for physical activity as one of their main reasons, shown in the following fragments:

The main cause I practice is because I love sports ( $P$. 24). 25).

The cause I practice sports is because I love sports ( $P$.

Other reasons expressed, to a lesser extent by both men and women, are: aesthetics, emotional and mental control, socialization, professionalization, obligation and earning money.

Resistance to the practice of physical activity by students

Next, the coded narratives that warn of the main causes of resistance on the part of the students towards physical activity and sports are exposed (see table 1.2).

\begin{tabular}{|c|c|c|}
\hline \multirow[t]{2}{*}{ Codes } & \multicolumn{2}{|c|}{ Participants narratives } \\
\hline & $\mathrm{AF}$ & $\mathrm{AF} \%$ \\
\hline 1.2.1 Laziness/inertia & 9 & 2,86 \\
\hline 1.2.2 Lack of time & 111 & 35,35 \\
\hline 1.2.3 I prefer other activity & 20 & 6,36 \\
\hline 1.2.4 Illness & 12 & 3,82 \\
\hline 1.2.5 I feel insecure / fearful & 5 & 1,59 \\
\hline 1.2.6 Economic, transport or others difficulties & 4 & 1,27 \\
\hline 1.2.7 I don't like, distaste & 3 & 0,95 \\
\hline Total Disaffections & 164 & 52.22 \\
\hline Whithout disaffection & 150 & 47,77 \\
\hline
\end{tabular}

Table 1.2 shows that the main reason is the lack of time. The following piece of text expresses the experience of the participants in relation to the lack of time:

Due to lack of time due to university studies (P. 5).

Another reason corresponds to the preference for other activities, highlighting the use of social networks as one of the main activities:

Because in my free time I do other activities that seem more fun to me, like the use of social networks (P.165).

Finally, the narratives in which respondents argue that they do not perform physical activity due to laziness, insecurity, illness or because they do not like it appear less frequently.

\section{Metaphoric Thought}

As we explained at the beginning, they were asked to build a metaphor that represented what sense the PAS had in their personal lives. When analyzing the metaphors, there were six different categories in which the conception of PAS as a vital necessity, something idealized, had the highest frequency of metaphors. On the contrary, the PAS as a profession or fun were not relevant (see table 1.3).

\begin{tabular}{|c|c|c|}
\hline PAS for me is like.. & \multicolumn{2}{|c|}{ Participants narratives } \\
\hline Codes & $\mathrm{AF}$ & $\mathrm{AF} \%$ \\
\hline 1.3.1 A vital and essential necessity & 49 & 28,48 \\
\hline 1.3.2 A mental and emotional heal & 32 & 18,60 \\
\hline 1.3.3 Physical Health & 54 & 31,39 \\
\hline 1.3.4 Self-improvement & 16 & 9,30 \\
\hline 1.3.5 Fun / Socialization & 19 & 11,04 \\
\hline 1.3.6 Professionalization/Competition & 2 & 1,16 \\
\hline TOTAL & 172 & \\
\hline
\end{tabular}

The metaphors that highlight the importance of AFD for health, followed by those that express an imperious and vital need that you could not do without are the most numerous:

Physical activity is an oak full of strength and life.

Physical activity is like an impetuous river that seeks to provide solutions to social and personal problems.

Physical and activity sports is a morning walk that gives you the wonderful things in life.

PAS is a problem turned into a challenge, and your tiredness turned into greatness.

The sport is like a paradise.

Physical Education is like a breath.

It is relevant to highlight in the design of metaphors, students show a great expressive force.

Students' perceptions regarding their physical education teachers

The answer to the question about actual teachers who exhibit a quite good opinion about teacher contrasting with a lower appreciation of the methodologies (table 2.1).

\begin{tabular}{|c|c|c|}
\hline \multirow[t]{2}{*}{ Codes } & \multicolumn{2}{|c|}{ Participants narratives } \\
\hline & $\mathrm{AF}$ & $\mathrm{AF} \%$ \\
\hline 2.1.1 Good methodologies & 42 & 10,79 \\
\hline 2.1.2 Good teacher & 203 & 52,18 \\
\hline Total & 245 & 62,98 \\
\hline 2.1.3 Inadequate methodologies & 89 & 22,87 \\
\hline 2.1.4 Unskilled teacher & 55 & 14,13 \\
\hline \multirow[t]{2}{*}{ Total } & 144 & 37,0 \\
\hline & 389 & \\
\hline
\end{tabular}

Table 2.1 highlights the satisfactory opinions of the interviewees through the code about teachers. Even though a majority consider that their teachers have been excellent and well prepared and have used appropriate methodologies, the code inappropriate methodology appears as another reason for dissatisfaction. Following is a fragment of the narratives that record the positive experiences:

I think they do their job well and are trained (P. 285).

Reflecting the negative experience, we present the following text units:

The physical education teachers were strict and the physical activities were basically the same every year and no specific sport was strengthened, I think they lacked preparation (P. 99).

I think they need to encourage more physical education activity with new methods that make it more interesting and fun (P. 280).

Although there is a higher percentage of positive perceptions, it should be noted that both positive and 
negative perceptions are directly related to the methodology in the teacher's learning and preparation process. It will depend on the perception that students have.

\section{Metaphoric vision of PAS teachers}

The construction of one metaphor that reflected the image of an PAS teacher was done by half of the participants (table 2.2).

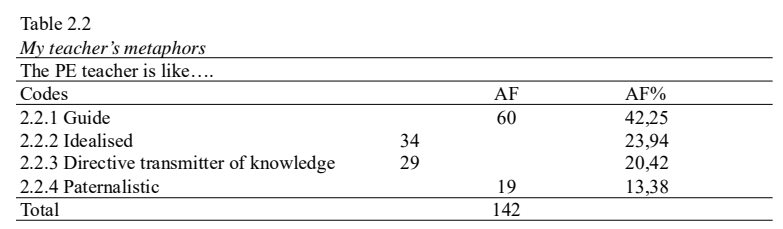

The metaphors designed by the participants involve four basic interpretations. The less predominant metaphors are that which contains a meaning of a paternalistic and a transmitting and directing professor.

The transmitting and directing professor:

A teacher is an open book.

The paternalistic professor:

The gentle ogre, the teacher.

The teacher is like a grandfather, his teachings do not forget them.

The idealized teacher:

The physical education teacher is like the sea because his daily mission is a whole.

The teacher guides your way to touch the sky with your hands.

Finally, the teacher code as a guide, the majority metaphor:

The teacher is a great carpenter who builds the student as a true human being.

The Physical Education teacher is an engine that starts and drives us.

The teacher is the one who shows the path that builds your knowledge.

The teacher is like the foundation of a house.

Expectations regarding the continuity in the physical and sports activity that you practice

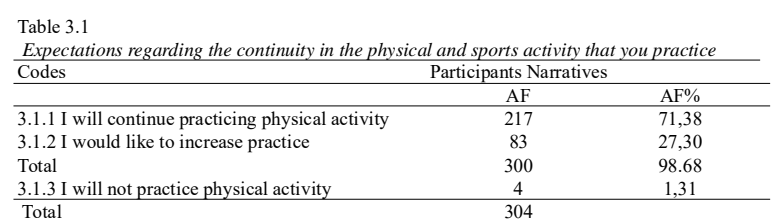

Finally, we reflect the results obtained from the question about future expectations about the practice of PAS in their free time.

Table 3.1 shows that the positive responses represent the greatest presence and also the increment code is relevant:

I plan to continue practicing, because physical activity provides me with a good state of physical and mental health (P. 82).

I plan to increase the time I dedicate to the practice of sports, because I am aware of the importance and benefits that it gives to the physical and emotional well-being of people (P. 59).

\section{Codes Interrelation}

It is essential to emphasize the interrelationships between codes in the results, considering the satisfaction, codes 1.1 with 372 narratives, centered on personal satisfaction and health; we see that it greatly exceeds the signs of dissatisfaction or resistance, codes 1.2 with 164 narratives, nucleated in lack of time.

Connecting categories Satisfaction, codes 1.1 and Metaphors, codes 1.3, the metaphors that represent the value granted to the AFD in their personal life, coincide exactly with the satisfaction expressed, since they both focus on how the PAS is a vital necessity for themselves and their health (Sfard, 2009).

In the results of his opinion on the university teaching staff of PAS, we find a positive interrelation of codes: good methodology (code 2.1.1) and good teaching staff (code 2.1.2) while although there is also some negative perception, it is perceived more as inadequate methodology (code 2.1.3) than inadequate teaching staff (code 2.1.4). Altogether, positive perceptions surpass negative opinions (see table 2.1).

Linking the results of the table 1.3 Physical activity and sports metaphors and the results of table 2.2 My teacher's metaphors, we can conclude that their metaphorical vision is what will guide them in their teaching career, although it is a highly idealized vision, it is also a positive vision of the teacher as a guide for their students' learning.

Given the results of this codes, it is understandable the high future expectations of PAS practice in their spare time, agglomerated on the expectations of continuing (code 3.1.1) and increasing the practice (code 3.1.2), which is $98,68 \%$ of the answers (see table 3.1). Notwithstanding the narratives that expressed some kind of resistance, only a $1.31 \%$ say they don't want to know anything about PAS in the future. Could be the fact that a $35.35 \%$ was due to lack of time, participants think that after university they can have more free time (see table 1.2).

Likewise, the perception of inadequate teachers' methodologies (code 2.1.3) seems not to have negatively influenced future abandonment by being counteracted with a very positive intuitive teacher's vision.

\section{Discussion and Conclusions}

What motivation and resistance to the practice of physical activity and sports do the students of the Central University of Ecuador express?

Our findings coincide with those made by McDavid et al. (2014), about the strength of satisfaction and motivation to act as predictors of high practice expectations Behzdnia et al. (2018). The results obtained on motivation in the practice of PAS as a means of emotional and physical health of students has been a coincidental finding in several investigations. However, as Adams et al. (2006) points out, it is necessary for universities to include in their curriculum knowledge the need for physical activity and sports for health and availability of resources.

Our results also converge with other research on motivation to perform physical activity and sports, such as enjoyment, and entertainment, often emerging in the 
narratives of the interviewees (Fradeja \& Espada, 2018). These results coincide with those found by Wallhead, Garn and Vidoni (2013) and Poldin, Valeeva and Yudkevich (2016), being fit and making new friends inform the reasons for social approval and demonstration of skills. However, the low value granted by participating students to socialization in the practice of PAS cannot be ignored because the self-regulation of the practice of PAS is also a product of interpersonal interactions. In other study conducted with adolescents the socializing function of sport and what it entailed in entertainment was much more present. This can lead us to conclude that although the value of the competition is not very present, neither is the team and collaboration vision to achieve the goals. It seems that the participants are not aware or value the socialization that sports practice produces. Perhaps too individualistic teaching has influenced their perspectives. Therefore, in the initial studies of Physical Education and Sports, it is necessary to work with more collaborative methodologies and underline the need to develop social skills in this field. Wallhead et al. (2013), sports practice can be highly relevant in the construction of affiliation and enjoyment motivations. For example, Van den Berghe, Vansteenkiste, Cardon Kirk and Haerens (2014) points out how many students practice AFD for enjoyment and for the emotion inherent in the task. Therefore, the scarce presence of the perception of physical activity as a means of socialization and fun among the participating university students is worrying. It is possible that students from both countries where climate and customs favour life outside the home do not need PAS to socialize.

In relation to the resistance to the practice of physical activity, one of the main reasons is the lack of time (35.35\%) for university studies, with a percentage It should also be noted that in the results of the causes of disaffection To the physical and sports activity, a group of students have appeared that state that they prefer other activities (6.36\%). The participants report that they prefer to carry out activities such as the use of social networks, or reading, manifestations that coincide with the study of (Ávalos et al., 2017).

\section{What image of the PAS faculty do the students of the University of Central Ecuador perceive?}

Regarding the question of research on the perceptions that students have regarding their physical education teachers, it is worth highlighting the satisfactory experiences of the students against the unsatisfactory ones. As participants perceive university education as inadequate, mainly because of the inadequate methodology with which they learned. Similarly, teachers continue to handle traditional and decontextualized teaching in relation to the real situations of student play and physical education teachers do not have enough training to teach the subject.

The positive perceptions of the students about their physical education teachers who express that they master the subject they teach, constitute an important starting point to encourage physical activity habits that influence the development of healthy lifestyles. The type of teacher that most influences interest in the subject or sport practice is the democratic teacher, concerned about his students being optimistic and cheerful. It is necessary to point out that the motivational climate, the type of feedback conferred by the teacher and the level of satisfaction obtained in the classes influences the importance that the student assigns to the subject and the intention to be active in the future. These results lead to the conclusion following Martínez et al. (2017), that the conceptions and positive perceptions of the students have about their Physical Education teacher become a relevant factor in the assessment of the practice of physical activity and sports.

\section{Which expectations of practice of physical activity and sports do the students of the Central University of Ecuador} maintain?

The results of this codes make understandable the high future expectations of PAS practice in their spare time that agglomerated on the expectations of continuing and increasing the practice (codes 3.1 and 3.1.2), which is consistent with the positive results of its motivation and satisfactions, as well as the presence of a metaphorical vision of the highly enthusiastic professor (Sfard, 2009).

We can conclude that both the satisfaction and motivation which students receive by playing sport, the positive vision of their teachers, their thinking and beliefs reflected in their metaphors, predict that the positive results of their high expectations of sports practice strengthens us in the prospects of motivation and self-determination (Reeve \& Cheon, 2016).

Finally, through the analysis it can be confirmed that the categories created respond to the stated objectives and have allowed us to reach the final conclusions and the prospects of the investigation. Likewise, research through metaphors has shown a useful tool to deepen the beliefs of the participants, which is fully corroborated in the studies of Martínez et al. (2017); Martýìnez, Sauleda and Huber (2001) and Mahlios et al. (2010), that emphasize that their value is also that the intervention alternatives can be planned based on the participants' speeches.

\section{References}

Adams, T.M., Graves, M.M., \& Adams, H.J. (2006). The effectiveness of a University Level Conceptually-based health-related fitness course on health-related fitness knowledge. Physical Educator, Urbana, 63, 104-112.

Asún, S., Fraile, A., Aparicio, J.L., \& Romero, MR. (2020). Dificultades en el uso del feedback en la formación del profesorado de Educación Física. Retos. Nuevas Tendencias en Educación Física, Deportes y Recreación, 37, 85-92. Edición web.

Ávalos, M.A., Martínez, \& Merma, G(2017).La disposición hacia la actividad física y deportiva: narrativas de los adolescents escolarizados. Sportis Sci J, 486-504.

Ayvazo, S., Ward, P., \& Stuhr,P. T. (2010). Teaching and assessing content knowledge in preservice physical education. Journal of Physical Education, Recreation \& Dance, 81(4), 40-44.

Behzadnia, B.,Adachi, P., Deci,E., \& Mohammadzadeh,H.(2018). Associations between students' perceptions of Physical Education teachers' interpersonal styles and students' wellness, knowledge, performance, and intentions to persist 
at physical activity: Aself-determination theory. Psychology of Sport and Exercise, 39, 10-19.

Brick, N., MacIntyre, T., \& Campbell, M. (2015). Metacognitive processes in the self-regulation of performance in elite endurance runners. Psychology of Sports and Exercise, 19, $1-9$.

Beltrán, V.J., Sierra,A.C., Jiménez,A., González-Cutre,D., Martínez, C., \& Cervelló, E. (2017). Diferencias según género en el tiempo empleado por adolescentes en actividad sedentaria y actividad física en diferentes segmentos horarios del día. Retos, Nuevas Tendencias en Educación Física, Deportes y Recreación, 31,3-7.

Cecchini, J., González, C., Carmona, A., Arruza, J., Escartí,A., \& Balagué, G. (2001) The influence of the physical education teacher on intrinsic motivation, self-confidence, anxiety, and pre- and post-competition mood states, European Journal of Sport Science, 1, 1-11,

Cheon, SH., Reeve, J., \& Ntoumanis, N. (2018). Aneeds-supportive intervention to help PE teachers enhance students' prosocial behaviour and diminish antisocial behaviour. Psychology of Sport \& Exercise, 35, 74-88.

Cloes, M. (2017). Preparing physically educated citizens in physical education. Expectations and practices. Retos, Nuevas Tendencias en Educación Física, Deportes y Recreación, 31,245-251.

Chen, W., \& Hypnar, A.J. (2015). Elementary school students' self-determination in physical education and altitudes toward physical activity. Journal of Teaching in Physical Education, 34, 189-209.

Cothran, D. J., Kulinna, P.H., Banville, D., Choi, E., Amade-Escot, C., MacPhail,A., MacDonald, D., Richard, J.F., Sarmento, P., \& Kirk, D. (2005). A cross-cultural investigation of the use of teaching styles. Research Quarterly for Exercise and Sport, 76(2), 193-201.

Cox, A., Duncheon, N., \& McDavid, L. (2009) Peers and Teachers as Sources of Relatedness Perceptions, Motivation, and Affective Responses in Physical Education, Research Quarterly for Exercise and Sport, 80, 765-773.

Deci, E.L., \& Ryan, R.M.(2016). Optimizing students'motivation in the era of testing and pressure. Aself-determination theory perspective. In J. Wang, C.W. Liu, \& R.M. Ryan (Eds.), Building autonomous learners: Research and practical perspectives using self-determination theory (pp. 9-29). Singapore: Springer.

De Meester,A., Haerens, L., \& Cardon, G. (2017). Extracurricular school-based sports as a stepping Stone toward an active lifestyle? Differences in physical activity and sportsmotivation between extracurricular school-based sports participants and non-participants. Journal of Teaching in Physical Education, 36, 485-497.

Enright, E., Coll, E., Ní Chróinín, D., \& Fitzpatrick, M. (2017). Student voice as risky praxis: democratizing Physical Education Teacher Education. Physical Education and Sport Pedagogy, 22, 459-472.

Fradejas, E., \& Espada, M. (2018). Evaluación de la motivación en adolescentes que practican deporte en edad escolar. Retos, Nuevas Tendencias en Educación Física, Deportes y Recreación, 33, 27-33.

Golpe, S., Isorna, M., Gómez,P., \& Rial,A.(2017).Usoproblemático de Internety adolescentes: el deporte sí importa. Retos, Nuevas
Tendencias en Educación Física, Deportes y Recreación, 31,52-57.

Gómez, M., Sánchez, D., \& Labisa,A. (2020). Actividad física en tiempo libre en estudiantes universitarios colombianos. Retos, Nuevas tendencias en Educación Física, Deporte y Recreación, 37, 181-189. Edición web.

Guthold, R., Stevens, G.A., Riley, L.M., \& Bull, F.C. (2018). Worldwide trends in insufficient physical activity from 2001 to 2016: a pooled analysis of 358 population-based surveys with 1.9 million participants. Lancet Glob Health, 6, e107786.

Gutiérrez, M.,Tomás. J.M., \& Catalayud. P.(2017). Influencia del clima motivacional en educación física sobre las metas de logro y la satisfacción con la vida de los adolescentes. Retos, Nuevas Tendencias en Educación Física, Deporte y Recreación, 31, 157-163.

Haerens, L., Kirk, D., Cardon, G., De Bourdeaudhuij, I., \& Vansteenkiste, M. (2010). Motivational profiles for secondary school Physical Education and its relationship to the adoption of a physically active lifestyle among university students. European Physical Education Review, 16, 117139.

Hernández, M.J., \& Martínez, MA. (2017). Principals’ metaphors as a lens to understand how they perceive leadership. Educational Management Administration \& Leadership, 46,602-623.

Hill, Y., Den Hartig, R., Meijer, R., De Jonge, P., Van Yperen, N. (2018). Resilience in Sports from a dynamical perspective. Sport, Exercise and Performance Psychology, 7, 333-341.

Huber, GL., \& Gürtler, L(2013), Aquad 7. Manual del programa para analizar datos cualitativos. Túbingen: Günter Huber.

INEC- Instituto Ecuatoriano de Estadísticas y Censos (2015). Compendio de Resultados Encuesta de VidaECV, sexta ronda 2015, Quito: INEC.

Kahneman, D., \& Tversky,A.(Eds.) (2000) Choices, values and frames. New York: Cambridge University Press.

Kahneman D. (2011) Thinking, Fast and Slow. Farrar, Straus and

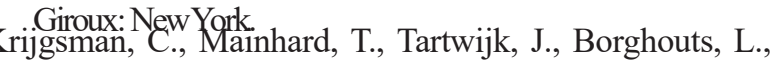
Vansteenkiste, M.,Aelterman, N., \& Haerens,L. (2019). Where to go and how to get there: goal clarification, process feedback and students' need satisfaction and frustration from lesson to lesson. Learning and Instruction, 61, 1-11.

Lakoff, G., \& Johnson, M. (1990). Philoshofy in the flesh. The embodied mind and its challenge to western thought. New York: Basic Books.

Larsson, H., \& Quennerstedt, M. (2016). Same, same but different: understanding the place of context in Physical Education practice. Recherches \& Éducations, 15, 69-86.

Li, F., Chen, J., \& Baker, M. (2014). University student's attitudes toward Physical Education teaching. Journal of Teaching in Physical Education, 33, 186-212.

Mahlios, M., Massengill Shaw, D., \& Barry,A. (2010). Making sense of teaching through metaphors: a review across three studies. Teachers and Teaching: theory and practice, 16, 49-71.

Martýìnez, M.A., Sauleda, N., \& Huber, G. L. (2001). Metaphors as blueprints of thinking about teaching and learning. Teaching and Teacher education, 17(8), 965-977.

Martínez, M.A., Ávalos, M.A., \& Merma, G. (2017). Inquiring 
sport and physical activity students' perceptions using metaphors as research tools. Retos, 32, 119-123.

Martins, J., Cabral, M., Elias, C., Nelas, R., Sarmento, H., Marques, A., \& Nicola, P. (2019). Physical activity recommendations for health: knowledge and perceptions among college students. Retos, Nuevas Tendencias en Educación Física, Deportesy Recreación, 36, 290-296.

McDavid,L., Cox,A., \& McDonough, M.(2014). Need fulfillment and motivation in physical education predict trajectories of change in leisure-time physical activity in early adolescence. Psychology of Sport and Exercise, 15, 471-480.

Ministerio del Deporte de Ecuador. (2012). El deporte en cifras. Quito. Descargado el día 3 de junio de 2018: http: //goo.gl/ U2g7KA.

Morgan, P., \& Hansen, V. (2008). Classroom teachers'perceptions of the impact of barriers to teaching Physical Education on the quality of Physical Education programs. Research Quarterly for Exercise and Sport, 79, 506-516.

OMS. 2018. WHO Global Action Plan on Physical Activity 20182030. More active people for a healthier world.https:// www.who.int/ncds/prevention/physical-activity/gappa/ action-plan

Poldin, O., Valeeva, D., \& Yudkevich, M. (2016). Which Peers matter: How social ties affect peer-group. Res High Education, 57, 448-468.

Reeve, J., \& Cheon, S.H. (2016). Teachers becomemore autonomy supportive after they believe it is easy to do. Psychology of Sport and Exercise, 22, 178-189.

Reeve, J, Ryan, R.M., Deci, E.L., \& Jang, H. (2008). Understanding and promoting autonomous self-regulation: A selfdetermination theory perspective. Motivation and Selfregulated Learning: Theory, Research and Applications, 223-244.

Rhodes, R., McEwan, D., \& Rebar,A. (2019). Theories of physical activity behaviour change: A history and synthesis of approaches. Psychology of Sport \& Exercise, 42, 100-109.

Romar, J., Åström, P., \& Ferry, M. (2018). Practical knowledge of preservice physical education teachers: Content and influence of acculturation. Journal of Physical Education and Sport, 18, 114-126.

Ryan, R. M., \& Deci, E. L. (2017). Self-determination theory: Basic psychological needs in motivation, development, and wellness. Guilford Publications.

Ryan, R.M., \& Deci, E.L. (2019). Brick by brick: The origins, development and future of self-determination theory. Advances in Motivation Science, 6, 111-156.

Saban, A., Kocbeker, B.N., \& Saban, A. (2007). Prospective teachers' metaphorical conceptions of teaching and learning revealed through metaphors analysis. Learning and Instruccion, 17, 123-139.

Saban, A. (2010). Prospective teachers' metaphorical conceptualizations of learner. Teaching and Teacher Education, 26, 290-305.

Secretaría del Deporte (2012). Ejes estratégicos. Gobierno de la República de Ecuador. Recuperado de: https:// www.deporte.gob.ec/ejes-estrategicos/

Serra, J.R., Zaragoza, J., \& Generelo, E. (2014). Influencias de «otros significativos» para la práctica de actividad física en adolescentes. Revista Internacional de Medicina y Ciencias de la Actividad Física y el Deporte, 14, 735-753.
Sfard, A. (2009). Metaphors in education. In H. Daniels, J.Porter \& H. Lauder (Eds.)., Educational theories, cultures and learning: A critical perspective (pp. 39-49). London Routledge.

Sfard, A., \& Prusak, A. (2005). Telling identities: in search of an analytic tool for investigating learning as a culturally shaped activity. Educational Researcher, 34, 14-22.

Shen, B., Li, W., Sun, H., \& Bernard, P. (2010). The influence of inadequate teacher-to-student social support on amotivation of Physical Education students. Journal of Teaching in Physical Education, 29, 417-432.

Taylor, I. (2017). Reciprocal effects of motivation in Physical Education and self-reported physical activity. Psychology of Sport and Exercise, 31, 131-138.

Taylor, I., Boat \& Stephen, R., \& Murphy, L. (2018). Integrating theories of self-control and motivation to advance endurance performance, International Review of Sport and Exercise Psychology, 1-20.

Van den Berghe, L., Vansteenkiste, M., Cardon, G., Kirk, D., \& Haerens, L. (2014). Research on self-determination in physical education: Key findings and proposals for future research. Physical Education and Sport Pedagogy, 19, 97121.

Van der Horst, K., Paw, M.J., Twisk, J.W., Van Mechelen, W. (2007). A brief review on correlates of physical activity and sedentariness in youth. Med Sci Sports Exercise, 39, 124150.

Van Raalte, J., Vincent,A., \& Brewer, B. (2016). Self-talk: Review and sport-specific model. Psychology of Sport and Exercise, 22,139-148.

Wallhead, T.L., Garn,A. C., \& Vidoni, C. (2013). SportEducation and social goals in physical education: relationships with enjoyment, relatedness, and leisure-time physical activity. Physical Education and Sport Pedagogy, 18(4), 427441.

Weinberg, R., Tenenbaum, G., McKenzie, A., Jackson, S., Anshel, M., Grove, R., \& Fogarty, G. (2000). Motivation for youth participation in sport and physical activity: Relationships to culture, self-reported activity levels and gender. International Journal of Sports Psychology, 31, 321-346.

Whitehead, A., Jones, H., Williams, E., Rowley, C., Quayle, L., Marchant, D., Polman, R. (2018). Investigating the relationship between cognitions, pacing strategies and performance in $16.1 \mathrm{~km}$ cycling time trials using a think aloud protocol. Psychology of Sport \& Exercise, 34, 95-109.

Whittle, R. J., Telford,A., \& Benson, A. C. (2015). The» Perfect» Senior(VCE) Secondary Physical Education Teacher: Student Perceptions of Teacher-Related Factors That Influence Academic Performance. Australian Journal of Teacher Education, 40(1). http://dx.doi.org/10.14221/ajte.2015v40n8.1

Woods, C.B., Tannehill, D., \& Walsh, J. (2012). An examination of the relationship between enjoyment, Physical Education, physical activity and health in Irish adolescents. Irish Educational Studies, 31, 263-280. 